Magdalena Mruszczyk

\title{
Fenomenologia polska przełomu XX i XXI wieku na obczyźnie. Kluczowe założenia fenomenologii życia Anny Teresy Tymienieckiej
}

\section{Wstęp: obczyzna - polszczyzna}

W 1987 roku Polskie Towarzystwo Naukowe na Obczyźnie wydało w Londynie szósty tom Prac Kongresu Kultury Polskiej zatytułowany Filozofia polska na obczyźnie. We wprowadzeniu, będącym pokłosiem obrad sekcji Filozofia polska na emigracji na Kongresie Kultury Polskiej w Londynie we wrześniu 1985 roku, redaktor Wiesław Strzałkowski napisał następujące słowa: „W tomie niniejszym przedstawiamy [...] rozprawy powstałe w różnych krajach osiedlenia, będące wyrazem studiów i przemyśleń w dziedzinie filozofii badaczy rozsianych po całym świecie, którzy szerza miłość Prawdy na obu

Magdalena Mruszczyk (ORCID 0000-0002-4025-0536) - doktor, adiunkt w Zakładzie Filozofii w Polsce Instytutu Filozofii Uniwersytetu Ślaskiego w Katowicach. Zainteresowania filozofią człowieka i związaną $z$ tym problematykę etyczną oraz epistemologiczną łączy $z$ badaniami nad filozofia polska, zwłaszcza w XX i XXI wieku. 
półkulach"1. Kultura polska i kultura w Polsce to wypadkowa wielu czynników, z których w historii filozofii polskiej na plan pierwszy przeważnie wysuwa się problematyka polityczna, historyczna i społeczna. Historyczno-społeczno-polityczny kontekst niejednokrotnie stawał się centralnym zagadnieniem rozważań polskich myślicieli, a w XX wieku, w perspektywie dokonującego się na świecie dynamicznego rozwoju naukowo-technicznego i technologicznego, jeszcze bardziej zyskał na znaczeniu. Pozwala to zreszta, a nawet obliguje, by dostrzec, że ostatecznym problemem leżącym u podstaw refleksji dotykajacej spraw politycznych, społecznych oraz historycznych relacji Polski $z$ innymi krajami i narodami były i sa kwestie etyczne. Słuszne zatem wydaja się słowa Strzałkowskigo zawarte w pokongresowym artykule:

W czasach obecnych, które przeżywamy, jesteśmy świadkami przerażającego obniżenia wartości moralnych, które przez długie wieki stanowiły trwałe podstawy współżycia pomiędzy ludźmi [...]. Zerwanie więzów pomiędzy etyka a polityka świadczy o samobójczych tendencjach ludzkości i grozi jej przy ogromnym rozwoju techniki zagłada, przed którą jedynym ratunkiem jest powrót na drogi wzajemnego zrozumienia i poszanowania podstawowych praw i obowiązków ${ }^{2}$.

Słowa te, choć napisane ponad trzydzieści lat temu, wciąż sa aktualne. Nie znaczy to wcale, że w polityce naszego kraju nic się od tego czasu nie zmieniło. Wręcz przeciwnie - dokonały się kolosalne zmiany. Podobnie jest w przypadku spraw społecznych i historycznego kontekstu życia narodu polskiego. Tutaj zmieniła się chociażby perspektywa postrzegania przeszłości i patrzenia w przyszłość. Nie chodzi przy tym o to, by wskazywać, co konkretnie nastapiło w Polsce czy Europie i na świecie. Nie będa tutaj analizowane wydarzenia będące wynikiem zmian, które zaszły w tym czasie, ale sam fakt zachodzenia zmian. Zmiana jest bowiem tym, co i w świecie

\footnotetext{
1 W. Strzałkowski, Zamiast wstepu, w: idem (red.), Prace Kongresu Kultury Polskiej, t. 6: Filozofia polska na obczyźnie, Polskie Towarzystwo Naukowe na Obczyźnie, Londyn 1987, s. 7.

2 Idem, Podstawy moralne polskiej myśli politycznej, w: idem (red.), Prace Kongresu Kultury Polskiej..., s. 40.
} 
przyrody, i w ludzkiej kulturze jest nieuniknione. Jest to fakt, który $z$ jednej strony napawa nadzieja na lepsze jutro, a $z$ drugiej rodzi niepokój nieuchronnego końca i refleksję nad sensem ludzkiego życia. Im szybciej zachodzą zmiany, tym większy wzmagają niepokój. Wydaje się, że niepokój ten oraz związana $z$ nim refleksja powoduja, że za amoralne nie można dziś obiektywnie postrzegać ani polityki ${ }^{3}$, ani nauki czy techniki ${ }^{4}$. Coraz częściej dostrzega się, że etyka jest fundamentem całokształtu ludzkiej działalności kulturotwórczej oraz że można, a nawet należy, mówić o pewnej etyce uniwersalnej - ogólnoludzkiej.

Edmund Husserl to już sztandarowy w historii filozofii współczesnej przykład myśliciela zatroskanego o losy kultury europejskiej. Jego zdaniem przeżywała ona głęboki kryzys etyczny w obliczu dynamicznie dokonujących się w jej obrębie zmian:

Narody europejskie, choć tak skłócone, łączy przecież pewne szczególne pokrewieństwo wewnętrzne, które przenika je wszystkie i wykracza poza różnice narodowe. Jest to jakby braterstwo, które w tym kręgu daje nam świadomość wspólnej ojczyzny. [...] Duchowy telos europejskiego człowieczeństwa, w którym zawarty jest telos poszczególnych narodów i pojedynczych ludzi, leży w nieskończoności, jest nieskończoną idea, ku której, by tak rzec, skrycie zmierza wszelkie duchowe stawanie się. Skoro uświadomiony został w rozwoju jako telos, z konieczności stał się też praktycznym celem woli, i tak oto zapoczatkowane zostało nowe stadium rozwoju, kierowane przez normy i idee normatywne ${ }^{5}$.

Szczególnie ważne jest zwrócenie przez niego uwagi na fakt, że ostateczne źródło kryzysu kultury europejskiej tkwi w samej filozofii, w jej kondycji jako fundamentu wszystkich nauk. Dlatego zdaniem niemieckiego fenomenologa właśnie od filozofii, od opracowania nowego jej rozumienia, należy rozpocząć wieloaspektowy i dalekosiężny

\footnotetext{
3 M. Kuniński, Sprawiedliwość globalna: szlachetny ideał czy rzetelna teoria?, „Diametros” 2010, nr 26, s. 140.

4 Por. P. Singer, Jeden świat. Etyka globalizacji, przeł. C. Cieśliński, Książka i Wiedza, Warszawa 2006, s. 80-86.

5 E. Husserl, Kryzys europejskiego człowieczeństwa a filozofia, przeł. J. Sidorek, Wydawnictwo „Aletheia”, Warszawa 1993, s. 18-19.
} 
proces uzdrawiania szeroko pojętej humanistyki. Chociaż sam postulat Husserla nie był niczym oryginalnym w dziejach filozofii, to swoja idea uzdrawiania ludzkiego świata wywarł wielki wpływ na dwudziesto- i dwudziestopierwszowiecznych myślicieli.

W tym kontekście $z$ problemem współczesności zmierzyła się na Kongresie Kultury Polskiej w Londynie Anna Teresa Tymieniecka (1923-2014), reprezentujaca polska emigrację w Stanach Zjednoczonych Ameryki Północnej jako członkini Polskiego Towarzystwa Naukowego na Obczyźnie od 1970 roku ${ }^{6}$. Już na początku wygłoszonego tam referatu mówiła:

Aby człowiek współczesny odnalazł orientację w życiu, kosmosie i świecie, należy znaleźć „punkt Archimedesa”, w którym wszelkie perspektywy „porzadku rzeczy” - racjonalności - nie tylko zbiegaja się, ale maja swoje źródło. Jako taki punkt w tym referacie będzie przedstawiony akt twórczy człowieka w kondycji ludzkiej ${ }^{7}$.

Słowa te sa kwintesencja koncepcji fenomenologii życia i ludzkiej kondycji twórczej, pomyślanej przez jej autorkę jako platforma rozwoju naukowego w ogóle. Fenomenologia życia Tymienieckiej była, po pierwsze, mocno inspirowana Husserlowska idea fenomenologii jako nauki opartej na analizie ludzkiego, niepowattpiewalnego (in evidence) doświadczenia ${ }^{8}$, a po drugie (i w związku z pierwszym), jawiła się jako koncepcja interdyscyplinarnego dialogu na płaszczyźnie doświadczenia życia w szeroko pojętej działalności kulturotwórczej człowieka: naukowej (natural science), filozoficznej, artystycznej (związanej ze sztukami pięknymi), jak również religijnej. Zadaniem, jakie Tymieniecka postawiła fenomenologii życia w przy-

\footnotetext{
6 Zob. III wybór członków Polskiego Towarzystwa Naukowego na Obczyźnie (http://docplayer.pl/3013168-Iii-wybor-czlonkow-polskiego-towarzystwa-naukowego-na-obczyznie. html).

7 A.T. Tymieniecka, Zagadnienia filozoficzne naszych czasów. Akt twórczy człowieka jako ostateczne źródło racjonalności, w: W. Strzałkowski (red.), Prace Kongresu Kultury Polskiej..., s. 68.

8 L.P. Torjussen, J. Servan, S. Andersen Øyen, An Interniew with Anna-Teresa Tymieniecka, (http://www.phenomenology.org/images/Interview-A-T-Tymieniecka-27-August-2008.pdf), s. 5 .
} 
padku religii, było przy tym pokazanie i zrozumienie, jak kształtuja się pojęcia religijności i świętości9.

Wydaje się, że taka wizja filozofii towarzyszyła Tymienieckiej od samego początku jej drogi naukowej. Równocześnie $z$ kształceniem filozoficznym, które rozpoczęła po zdaniu egzaminu maturalnego w sosnowieckim gimnazjum w 1945 roku i do 1947 roku kontynuowała na Uniwersytecie Jagiellońskim pod kierunkiem Romana Ingardena (przepracowując $\mathrm{w}$ tym czasie cały kurs filozofii przewidziany programem studiów), podjęła naukę na Akademii Sztuk Pięknych w Krakowie ${ }^{10}$. Swoja droga wpływ mistrza Ingardena skutkował tym, że pracę doktorska (obroniona nie w Polsce, ale w szwajcarskim Fryburgu) poświęciła między innymi jego fenomenologii ${ }^{11}$. Jak sama twierdziła, był to jedyny filozof, $z$ którym w ogóle podjęła polemikę. Tę zaś rozumiała jako kłótnię, w toku której wprowadza się do czyjejś teorii zupełnie obce jej argumenty. Sama nie chciała tego czynić, uważając, że nikt nie może rościć sobie pretensji do ortodoksji. Tylko otwartość na ludzkie doświadczenie w każdej jego formie i treści może dawać perspektywę coraz głębszego wglądu w świat życia i coraz szersze horyzonty jego rozumienia ${ }^{12}$.

Trzeba przyznać, że kulturowe i duchowe horyzonty Tymienieckiej były naprawdę szerokie. Wspomniany wyżej doktorat sfinalizowała w 1952 roku, a rok wcześniej obroniła na Sorbonie doktorat z filozofii i literatury francuskiej. Do rysu biograficzno-naukowego można jeszcze dodać fakt, że w celu uzyskania habilitacji studiowała w latach 1953-1954 na Uniwersytecie Saary w Niemczech, a po zdobyciu stopnia naukowego w 1955 roku wyemigrowała do Stanów Zjednoczonych. Za oceanem na dobre rozpostarła skrzydła swojego filozoficznego powołania, rozwijając autorską koncepcję

\section{Ibidem.}

10 Anna-Teresa Tymieniecka (https://en.wikipedia.org/wiki/Anna-Teresa_Tymieniecka).

11 Tymieniecka napisała dysertację na temat filozofii Romana Ingardena i Nicolaia Hartmanna. Praca ta została opublikowana pod tytułem: Essence et Existence. Etude a propos de la philosophie de Roman Ingarden et Nicolaï Hartmann, Editions Montaigne, Paris 1957.

12 L.P. Torjussen, J. Servan, S. Andersen Øyen, An Interniew with Anna-Teresa Tymieniecka..., s. 5 . 
fenomenologii życia i ludzkiej kondycji twórczej oraz pracując na kilku prestiżowych uczelniach, między innymi Uniwersytecie Kalifornijskim czy Yale ${ }^{13}$. Dopiero tam mogła zakładać kolejne towarzystwa naukowe skupiające badaczy różnych dziedzin (na przykład literatury), którzy dostrzegali potrzebę dialogu $z$ fenomenologia życia.

Słowo dopiero nie zostało tu użyte przypadkowo. Wracając pamięcią do czasów szwajcarskich, Tymieniecka dość gorzko wspominała swoje próby przebicia się na tamtejszym forum filozoficznym. Dużo zawdzięczała poznanemu w Helwecji Józefowi Marii Bocheńskiemu, który tak jak Ingarden w Krakowie stał się jej mistrzem na obczyźnie. To on pomógł jej wkroczyć na europejska scenę filozoficzna, co dla naukowca pochodzącego $z$ tej części kontynentu, a szczególnie dla kobiety, nie było zadaniem łatwym ${ }^{14}$. Ostatecznie jednak Tymieniecka nie znalazła tam miejsca ani dla siebie, ani dla swej rodzącej się już fenomenologii życia. Najwyraźniej w ogóle Europa nie oferowała jej tego, czego oczekiwała. Uważała bowiem, że naukę można rozwijać tylko w atmosferze pełnej wolności (duchowej i cielesnej) i przy zaspokojeniu określonych potrzeb ekonomicznych. Jedno i drugie było przedmiotem jej nieustannych i najczęściej skutecznych zabiegów, ale dopiero w USA.

Pierwsze zatrudnienie na uczelni wyższej w Stanach Zjednoczonych (Uniwersytecie Kalifornijskim) zawdzięczała żonie Alfreda Tarskiego ${ }^{15}$. Otworzyło jej to drzwi do wielu światowych ośrodków naukowo-badawczych, ale nie dawało pełnej satysfakcji, zwłaszcza finansowej. Realizacja dalekosiężnych zamiarów, jak organizowanie międzynarodowych kongresów fenomenologicznych, wymagała sporych nakładów. Dlatego też, piastując różne stanowiska na amerykańskich uczelniach, Tymieniecka zrezygnowała w końcu z pracy akademickiej, na pierwszym miejscu stawiając wolność w rozwijaniu nauki i samodzielność ekonomiczna. W tym ostatnim dużym

\footnotetext{
13 J. Szmyd, Tymieniecka Anna Teresa, w: idem (red.), Leksykon filozofów współczesnych, Oficyna Wydawnicza „Branta”, Bydgoszcz-Kraków 2004, s. 499.

14 Y.B. Raynova, In Memoriam Ana Teresa Tymieniecka, „Labyrinth” 2015, vol. 17 (2), s. 75.

15 L.P. Torjussen, J. Servan, S. Andersen Øyen, An Interniew with Anna-Teresa Tymieniec$k a \ldots$, s. 1.
} 
wsparciem był dla niej mąż, Hendrik Houthakker - profesor ekonomii $z$ Harvardu i biznesmen ${ }^{16}$.

Dzięki pracy na Uniwersytecie Kalifornijskim Tymieniecka nawiazała kontakt $z$ Tarskim, co zaowocowało ich cotygodniowymi dyskusjami na temat fenomenologii Husserla, prowadzonymi na podstawie lektury Badań logicznych (Logische Untersuchungen). Spotkania trwały około roku, a Tymieniecka starała się w tym czasie wykazać, że fenomenologia jest w stanie przejść pragmatyczny test, czyli że znajduje zastosowanie we współczesnej nauce. Jest to jednak fenomenologia życia, a nie abstrakcyjne analizy Husserla. Chęć przekonania Tarskiego, że fenomenologia ma zastosowanie pragmatyczne (na przykład w psychologii, psychiatrii, sztukach pięknych czy literaturze i w ogóle w krytycznej analizie naukowej), była bezpośrednim motywem napisania przez Tymieniecka książki Phenomenology and Science in the Contemporary European Thought ${ }^{17}$. Jak podkreślała autorka, publikacja ta cieszyła się w Ameryce wielkim zainteresowaniem, a jego przyczyna był przemawiajacy $z$ tekstu pragmatyzm, którego amerykańskiej mentalności nie oferowała klasyczna fenomenologia ${ }^{18}$. „Patrzac dzisiaj wstecz mówiła Tymieniecka w wywiadzie - widzimy, że fenomenologia weszła do wszystkich sektorów wiedzy, w tej samej mierze w praktykę, co w teorię. Fenomenologia jest dyskutowana w fizyce, w embriologii i gdzie indziej również - nie przez wszystkich oczywiście, ale przez niektórych. Jej znaczenie jest więc dzisiaj sprawą oczywistą, ale w 1955 roku było to zagadnienie problematyczne"19.

Działalność wydawnicza Tymienieckiej rozpoczęła się również dopiero na emigracji. Wiązała się głównie $z$ założona przez polska filozof seria wydawnicza "Analecta Husserliana. The Yearbook of Phenomenological Research”, której do końca życia była redaktor

\footnotetext{
16 Y.B. Raynova, In Memoriam Ana Teresa Tymieniecka..., s. 77-78.

17 A.T. Tymieniecka, Phenomenology and Science in Contemporary European Thought. With a Foreword by J.M. Bochenski, The Noonday Press, New York 1962.

18 L.P. Torjussen, J. Servan, S. Andersen Øyen, An Interniew with Anna-Teresa Tymieniecka..., s. 1-2.

19 Ibidem, s. 2.
} 
naczelną. Cykl ten pomyślany został jako kontynuacja Husserlowskiej „Jahrbuch für Philosophie und Phänomenologische Forschung" ${ }^{20}$. Prace wydawnicze rozpoczęto w 1968 roku, a pierwszy tom ukazał się w 1971. W 1976 roku ruszyła natomiast publikacja czasopisma „Phenomenology Information Bulletin”, przemianowanego w 1985 na „Phenomenological Inquiry. A Review of Philosophical Ideas and Trends" ${ }^{21}$. Oba tytuły to zbiory wyników badań fenomenologicznych prowadzonych przez naukowców $z$ całego świata, których polska filozof zapraszała na organizowane przez siebie w różnych częściach globu kongresy i sympozja naukowe. Czyniła to już $z$ ramienia Światowego Instytutu Wyższych Studiów Fenomenologicznych (World Institute for Advanced Phenomenological Research and Learning), którego była fundatorka (1976) i prezydentem ${ }^{22}$. Jednostka ta powstała na bazie trzech powołanych wcześniej towarzystw filozoficznych i funkcjonowała na prawach uniwersytetu $^{23}$. Obecnie działa pod nazwa Swiatowy Instytut Fenomenologii (The World Phenomenology Institute) ${ }^{24}$.

\section{Rozwinięcie: mathesis universalis Nowego Oświecenia}

Na wspomnianym wyżej kongresie w Londynie Tymieniecka zaproponowała własna koncepcję filozofii po prostu, która ma być płaszczyzna porozumienia dla wszystkich nauk oraz sztuki i literatury, a nawet teologii i religii. Myślicielka nie tylko prezentowała stan polskiej nauki na emigracji i polskiej kultury uprawianej na obczyźnie, ale za pośrednictwem fenomenologii życia, jak nazwała tę koncepcję, chciała dotrzeć do aksjologicznych, a szczególnie

${ }^{20}$ Anna-Teresa Tymieniecka (https://en.wikipedia.org/wiki/Anna-Teresa_Tymieniecka).

21 A. Szymaniak, Anna Teresa Tymieniecka, w: A. Maryniarczyk (red.), Encyklopedia filozofii polskiej, t. 2, Polskie Towarzystwo Tomasza z Akwinu, Lublin 2011, s. 760.

22 Ibidem, s. 759.

${ }_{23}$ Y.B. Raynova, In Memoriam Ana Teresa Tymieniecka..., s. 76.

24 Anna-Teresa Tymieniecka (https://en.wikipedia.org/wiki/Anna-Teresa_Tymieniecka). 
etycznych podwalin myślenia i działania człowieka jako człowieka w relacji $z$ innymi ludźmi i $z$ otaczającym go światem. Wskazanie tych fundamentów to zdaniem Tymienieckiej największe wyzwanie współczesnych nam czasów, które przez wzgląd na rozwojowe i postępowe w kwestiach naukowych i technicznych tendencje budzą w nas poczucie barbarzyńskości świata, w którym żyjemy ${ }^{25}$. Pisze ona, co następuje:

[...] obecne stadium ciagle postępującego zróżnicowania nauk, rozwijające się w najróżniejszych perspektywach, z których każda opiera się na wynalezieniu w układach życia, kosmosu i świata nowych form racjonalności, oraz stosowanie ich $\mathrm{w}$ technice życia codziennego dezorientuje człowieka aż do punktu zupełnej straty orientacji w świecie i życiu. Jest to spotęgowane faktem, że chaos wprowadzony w „zrozumieniu porządku rzeczy” w badaniach nauk i zróżnicowaniu ich poprzez wprowadzanie różnych „języków” odnośnie różnych form racjonalności zerwał wszelkie podstawy komunikacji między nimi. W rezultacie nauki nie sa w stanie porozumiewać się odnośnie porządku całości rzeczywistości. Jak zawsze w historii ludzkości, filozofii przypada dotrzeć „do sedna rzeczy” i zaproponować teren wspólny ${ }^{26}$.

Potrzebny jest język uniwersalny, w którym wszystkie formy racjonalności człowieka mogłyby ze soba dyskutować i porozumiewać się. Dzięki temu będzie można wyłożyć wszystkie prawidła porządku i miary. „Miara i zaangażowanie - pisze Tymieniecka - sa zawsze kluczowymi kwestiami w życiu, ale dzisiaj muszą być zbadane na nowo $z$ pełną świadomością rosnacych etycznych wymagań/ roszczeń zgłaszanych w naszych instytucjach, zawodach, sadach, rządach, porządku światowym"27. Stąd też paląca potrzeba zjednoczenia różnych dziedzin nauki, filozofii, sztuki i literatury oraz innych płaszczyzn ludzkiej twórczości, za sprawą których człowiek uzasadnia swoje istnienie, nie znajdując dla niego uzasadnienia

\footnotetext{
25 Zob. A.T. Tymieniecka, Życie $w$ pełni logos. Księga I: Metafizyka Nowego Oświecenia, przeł. M. Wiertlewska, Wydawnictwo Poznańskie, Poznań 2011, s. 11-14.

26 Eadem, Zagadnienia filozoficzne naszych czasów..., s. 67.

27 Eadem (red.), Logos and Life. Impetus and Equipoise in the Life-Strategies of Reason, Book 4, Singer, Dordrecht 2000 (Analecta Husserliana, 70), s. 616.
} 
$\mathrm{w}$ przyrodzie ${ }^{28}$. Zdaniem polskiej myślicielki zjednoczenie to może się dokonać tylko pod egidą fenomenologii, gdyż tylko ona odsyła bezpośrednio do podmiotu i stanowi układ odniesienia człowieka w całej rzeczywistości ${ }^{29}$. Myśl Tymienieckiej przedstawiona w wystapieniu na kongresie bardzo trafnie podsumował Strzałkowski, mówiąc, że „metodą fenomenologiczna poszukuje [ona] mathesis universalis, o której niegdyś marzył Leibniz" ${ }^{30}$. Jeszcze kilkanaście lat wcześniej polska filozof pisała zresztą:

Jawi się, że zarówno współczesne naukowe i fenomenologiczne badania przyjęły uderzająco pokrewną linię, angażując się coraz głębiej i głębiej w poznawcze dociekanie nieuchwytnej i zawsze odległej natury człowieka i wszechświata. Wydaje się, że postęp fenomenologii wniósł wkład do klasycznego ideału mathesis universalis tego otwartego horyzontu własnego postępu człowieka ${ }^{31}$.

Tymieniecka zwracała uwagę, że główny projekt fenomenologiczny Husserla, opierajacy się na przekonaniu, że pojmowanie filozofii jako podstawy wszelkiej ludzkiej wiedzy (mathesis universalis albo philosophiae prima) jest jej właściwym pojmowaniem, został tutaj w całości zachowany. Nie wyklucza to jednak faktu, że interpretacje klasycznej fenomenologii dokonane przez Tymieniecka akcentuja głównie różnice w poglądach Husserla i jej samej. Przede wszystkim należy wskazać odrzucenie przez polską myślicielkę idealizmu transcendentalnego. Polemika dotknęła również ontologię bytów możliwych Ingardena jako pewną formę transcendentalizmu ${ }^{32}$. Tymieniecka zwróciła uwagę, że Ingardena i Husserla, mimo różnic w fenomenologicznych stanowiskach, łączy aspekt rekonstrukcji filozoficznej rzeczywistości człowieka w świecie. Obaj też pozosta-

28 A.L. Zachariasz, W poszukiwaniu sensu, „Lọıa. Pismo Filozofów Krajów Słowiańskich” 2015, vol. 15, s. 327, 334.

29 A.T. Tymieniecka, Impet $i$ równowaga $w$ życiowych strategiach rozumu. Logos $i \dot{z} y c i e$, ks. 4, t. 1, przeł. M. Wiertlewska, Wydawnictwo Naukowe i Innowacyjne, Poznań 2014, s. 269.

30 W. Strzałkowski, Zamiast wstępu..., s. 7-8.

31 A.T. Tymieniecka, Logos and Life..., s. 346 (tłumaczenie własne).

32 J. Szmyd, Tymieniecka Anna Teresa..., s. 502. 
wali w tym zadaniu wyłącznie na racjonalno-poznawczej drodze ${ }^{33}$. Tymczasem zdaniem Tymienieckiej potrzebne jest przyjęcie pierwotnego charakteru konstrukcji, a nie poznania-konstytucji, oraz koncepcji żywego podmiotu, człowieka - jestestwa żyjącego w jedności-ze-wszystkim-co-żyje (within-the-unity-of-everything-there-is-alive) w perspektywie kosmologicznej, a nie transcendentalnej ${ }^{34}$. Dlatego podmiot w fenomenologii życia jawi się częścią empirii. Jest przede wszystkim żywy, a życie to świadomość w jej różnych stanach na poziomie różnych form organicznego świata, $z$ których najprostszą jest czucie ${ }^{35}$. Świadomość w sensie idealizmu transcendentalnego nie przedstawia żadnej formy życia, zupełnie się od życia odcinając. Najistotniejszymi elementami różniącymi fenomenologiczne stanowiska Husserla i Tymienieckiej (ważnymi z punktu widzenia kryzysu kultury europejskiej) sa dostrzegane przez polska fenomenolog dynamizm i zmienność życia oraz całej rzeczywistości, których w żaden sposób idealizm transcendentalny nie tłumaczy. Chociaż według Husserla wizja transcendentalnej świadomości, a konkretnie jej funkcji poznawczo-konstytutywnej, miała dostarczyć uniwersalny obraz całej rzeczywistości, to zdaniem Tymienieckiej stałość, skostniałość i bierność tego obrazu nie odpowiadają doświadczeniu życia ${ }^{36}$.

Nieco inna wizja mathesis uniwersalis wyłania się $z$ koncepcji filozoficznej Gottfrieda Wilhelma Leibniza. Oprócz trafności jego spostrzeżenia co do konieczności poznania źródła tego, czego rozumienie nas interesuje ${ }^{37}$, polska filozof podkreśliła szczególne zasługi tego myśliciela w poszukiwaniu pierwszych szyfrów (uniwersalnych cech) kodujących całą rzeczywistość i cały monadyczny świat, łącznie $z$ ludzkim umysłem. Leibniz zbliżył się tym samym do kosmologicznej syntezy wszystkich poziomów stworzenia, ale nie zdołał jej osiagnąć w pełni, gdyż nie udało mu się wykroczyć poza spekulację

33 A.T. Tymieniecka, Zagadnienia filozoficzne naszych czasów..., s. 70-71.

34 Eadem, Życie w petni logos..., s. 21, 28 i in.

35 Ibidem, s. 70-73 i in.

36 Ibidem, s. 70.

37 Ibidem, s. 105. 
metafizyczna ze względu na brak kręgosłupa, jakim jest życie. To życie nadaje rzeczywistości dynamizm i umożliwia stawanie się oraz rozwój. Bez uwzględnienia życia każda wizja jawi się ostatecznie jako statyczna ${ }^{38}$.

Tymieniecka odrzuciła więc koncepcję Leibniza o harmonii przedustawnej ${ }^{39}$, inaczej rozumiejac poczatek wszystkiego i zachowując dynamikę tego początku. Pisała ponadto:

Wraz $z$ twórczym zstępowaniem szlakiem szyfrowania logos przez życie wychodzimy od tego, co bardziej złożone, i przechodzimy do tego, co najmniej złożone, do najprostszych momentów istot żywych, a następnie od bardziej złożonych do najmniej złożonych ruchów i praw pierwotnego logos jako takiego. Jednak w naszym rejestrowaniu owego szyfrowania zaczynamy od początku, od zarejestrowania różnicowania się samego $\operatorname{logos}^{40}$.

Poszczególne nauki, teorie naukowe, nurty i koncepcje filozoficzne, ludzka działalność artystyczna, literatura, sztuka, jak również społeczeństwo (wspólnota) i moralność, teologia i religia - jednym słowem: różne formy racjonalności świata i człowieka w świecie są więc zgodnie $z$ powyższym cytatem przejawami różnicowania się pierwotnego logos życia i jednocześnie jego szyfrowaniem. Rozwikłanie tego szyfru mogłoby oznaczać zrozumienie początku wszystkiego, a może nawet Wszystkiego, co zresztą człowiek nieustannie stara się realizować. Założenie, że ów początek miał charakter uporządkowany, podobnie jak przyjęcie jego wyłącznie duchowej natury, jest jednak czystą spekulacją. Wychodzac z pozycji kosmologicznej, od życia, należy przyjąć, że ów początek nie był czymś nieruchomym, czekajacym na zdynamizowanie $z$ zewnątrz. Życie wybuchło u swojego zarania $z$ pierwotnego rezerwuaru sił, energii, dynamizmów i wirtualności, by móc dalej pędzić naprzód, niesione pierwotnym impetem i nieustannie harmonizowane równie pierwotna równowagą. Jak wynika $z$ rozważań Tymienieckiej obecnych w różnych pu-

38 A.T. Tymieniecka, Impet $i$ równowaga $w$ życiowych strategiach rozumu..., s. 42.

39 J. Szmyd, Tymieniecka Anna Teresa..., s. 502.

40 A.T. Tymieniecka, Impet i równowaga $w$ życiowych strategiach rozumu..., s. 42. 
blikacjach, ten pęd impetu i równowagi niosącej wraz z nim życie miał na celu wyewoluowanie ludzkiej kondycji twórczej, z ludzka samoświadomością i ludzkim umysłem ${ }^{41}$. Od tego momentu proces konstruktywnego rozwoju życia ludzkiego jest udziałem samego człowieka, wyrażając się jego samoindywidualizacją w świecie. Ta zaś przybiera postać samointerpretacji człowieka w egzystencji ${ }^{42}$.

Tutaj rodzi się fenomenologia życia i można tu dostrzec, dlaczego jest ona ontopojeza życia - jego konstruktywnym stawaniem się. Warto jeszcze dodać, że samointerpretacja człowieka w egzystencji, będąc ostatecznie samointerpretacją moralna (aksjologiczna), musi również moralnie szyfrować logos życia.

Poprzez nauki przyrodnicze, społeczne i humanistyczne, działalność artystyczna, tworzenie sztuki, literatury, a nawet swoje codzienne życie człowiek nie tylko szyfruje pierwotny logos, ale przede wszystkim dąży do jego odszyfrowania. Wydaje się, że w nadziei na zrozumienie poczattku Wszystkiego dostrzega on możliwość zrozumienia początku własnego jestestwa, w końcu majac nadzieję na zrozumienie ostatecznego - moralnego, transnaturalnego sensu swojego życia i realizację tym sposobem przeznaczenia ludzkiego jestestwa ${ }^{43}$. Co jednak niezwykle ważne, jeśli poszczególne eksplikacje ludzkiej twórczości składające się w postać ludzkiej kultury, w której człowiek szuka uzasadnienia swojego istnienia w świecie, i będace szyfrowaniem pierwotnego logos życia rozpatrywane będa każda $z$ osobna, nie pozwola na jego deszyfrację ${ }^{44}$. Oznacza to, że pozostając w obszarze tylko jednej dziedziny ludzkiej kultury - czy to nauk humanistycznych lub przyrodniczych, czy jakiejś konkretnej koncepcji filozoficznej, czy też potocznego światopogladu - w pewien sposób zamykamy sobie drogę do samej możliwości deszyfracji, o której tu mowa. Nieco lepsze perspektywy rysuja się przed formami kulturowymi odnoszącymi się stricte do sztuki, gdyż

${ }^{41}$ Eadem, Życie $w$ petni logos..., s. 239-247.

42 Ibidem, s. 19-20.

43 Ibidem, s. 15, 355.

44 A.T. Tymieniecka, Impet $i$ równowaga $w$ życiowych strategiach rozumu..., s. 43-44. 
rzeczywistość ciagle się staje, jest dynamiczna. „Innymi słowy pisze Tymieniecka - przenosimy metafizykę w ontopojezę życia"45.

Fenomenologia życia, która jest jego ontopojeza, przez swoją charakterystykę i swoistość staje się dla człowieka polem porozumienia różnych form racjonalności co do porządku całej rzeczywistości na miarę czasów najnowszych. W zamyśle Tymienieckiej pełni ona rolę uniwersalnego języka, realizując w nowej formie ideę mathesis universalis. Mówimy tu o formie nowej, bo jest ona twórczym sposobem szyfrowania logos życia przez samego człowieka. Sens życia w koncepcji fenomenologii życia nie jest przez człowieka odkrywany, odsłaniany jako coś już w pełni ukonstytuowanego, ale wykuwany w twórczej kuźni ludzkiej duszy ${ }^{46}$, czyli wynajdywany (invent) w procesie samoindywidualizacji i samointerpretacji człowieka w egzystencji, ostatecznie jako sens moralny.

Wyzwanie to może podjacc tylko metafizyka ludzkiego jestestwa, metafizyka Nowego Oświecenia. Właśnie $z$ nią wiąże się postulowana przez Tymieniecką nowa krytyka rozumu:

Fenomenologia człowieka w jego twórczej kondycji otwiera teren i środki komunikacji wszelkich rodzajów racjonalności w systemie wspólnego aktu twórczego człowieka. Krytyka rozumu przybrała w tej perspektywie nowa formę, „interdyscyplinarna” - mathesis universalis. Odpowiadając wymogom postępu wiedzy i metod badania naszych czasów, kontynuuje ona aspiracje Leibniza i całej filozofii współczesnej, idącej za intuicjami Arystotelesa ${ }^{47}$.

Tymieniecka porównuje obecna sytuację ludzkości z XVIII wiekiem, gdy pod wpływem odkryć naukowych zaczęto pytać o naturę racjonalności ${ }^{48}$ : „[...] jesteśmy faktycznie gotowi rozpocząć Nowe Oświecenie ludzkości”49 - pisze.

\footnotetext{
Ibidem, s. 43.

A.T. Tymieniecka, Logos and Life..., s. 569-589.

47 Eadem, Zagadnienia filozoficzne naszych czasów..., s. 77.

48 Eadem, Życie w petni logos..., s. 12-13.

49 Ibidem, s. 15.
} 


\section{Perspektywy badawcze: kluczowa rola wyobraźni w racjonalizacji życia}

Ani idealistyczna koncepcja świadomości transcendentalnej, ani monadologia Leibniza nie docieraja do twórczej intuicji, która w odróżnieniu od aktu intencjonalnego (przede wszystkim poznawczo-konstytutywnego i biernego) jest aktem konstruktywnym, a przez to dynamicznym. Twórcza intuicja wyłania się w fenomenologii życia pod postacią aktu twórczego człowieka. Jeżeli - jak uważa Tymieniecka wchodzimy, a nawet weszliśmy już w nową epokę tworzenia kultury - w Nowe Oświecenie, to zwiazana $z$ tym wydarzeniem misja odnowy rozumu i uzasadnienia racjonalności może zostać zrealizowana tylko pod warunkiem, że uda się ja przeprowadzić na nowej drodze. Zdaniem Tymienieckiej fenomenologia życia i ludzkiej kondycji twórczej jest taka droga, gdyż daje absolutny dostęp do konstruktywnej indywidualizacji życia ${ }^{50}$. Człowiek, za sprawa swojej twórczej kondycji, jest swoistym mikrokosmosem, niczym Leibnizjańska monada. Władzą naczelną tej monady nie jest jednak sam rozum, ale wyobraźnia Imaginatio Creatrix. Dzięki niej twórcze sa ludzka kondycja i każde ludzkie indywiduum. Dlatego już niemalże na koniec niniejszego opracowania raz jeszcze oddajmy głos samej Tymienieckiej:

Akt twórczy człowieka, orkiestrując w swoisty sposób wszystkie funkcje konstruktywne władz witalnych, a równocześnie używając ich do nowej funkcji: wynalazczej, jest punktem Archimedesa, z którego wypływaja wszystkie ludzkie racjonalności życia. Analiza fenomenologiczna człowieka w jego kondycji twórczej, jako badanie aktu twórczego życia, pozwala zbadać całość rozsiewu "porządku rzeczy” - od racjonalności elementarnych, witalnych zwiazków, poprzez wynalazcze racjonalności dróg życia specyficznie ludzkich ${ }^{51}$.

Akt twórczy człowieka, jako akt jego duszy, spaja funkcjonalna całość ludzkiego bycia w świecie, a zarazem pokazuje zakorzenienie

\footnotetext{
A.T. Tymieniecka, Zagadnienia filozoficzne naszych czasów..., s. 77.
}

51 Ibidem. 
człowieka w naturze i duchowe obszary wolności tworzenia przez niego własnego życia.

Tradycyjne ramy, w których rozum odnosi się do rzeczywistości, stały się dziś zbyt wąskie. Wyłaniają się nowe formy racjonalności, wymagające poszerzenia perspektyw postrzegania i rozumienia rzeczywistości, gdyż niosą ze sobą nową problematykę etyczną, która wymaga nowego, głębszego i szerszego spojrzenia na ludzki świat kultury i jego poszczególne elementy. Czysty rozum zdaniem Tymienieckiej nie spełnia już dzisiaj tego zadania, bo tak szerokie i dynamicznie zmienne perspektywy może śledzić tylko ten pierwiastek ludzkiego umysłu i ludzkiej kondycji, który sam wyznacza granice racjonalności, nieustannie je przekraczajac. Jest nim twórcza wyobraźnia człowieka, bez której, jak zdaje się uważać Tymieniecka, kultura ludzka ani nie powstanie, ani nie podźwignie się z kryzysu. Akt twórczy ludzkiego jestestwa, jako punkt Archimedesa, ma otworzyć przed nami podwoje do rozumienia wszystkiego, do rozumienia, które nie jest uchwyceniem tego, co jest, ale nieustanną wędrówka ludzkiego umysłu ścieżkami twórczych aktów. To wieczne zadanie człowieka - nie tylko intelektualne, ale także estetyczne i moralne. Akt twórczy to w wizji Tymienieckiej uniwersalny, wręcz kosmiczny język porozumiewania się człowieka $z$ człowiekiem i człowieka $z$ kosmosem, a nawet człowieka $z$ Transcendencja. Jest to zarazem aktualna perspektywa badawcza filozofii.

\section{Zakończenie}

Józef Maria Bocheński wskazał we wstępie do Phenomenology and Science in the Contemporary European Thought autorstwa Anny Teresy Tymienieckiej trzy typy czy też grupy filozofii, które dominowały w ówczesnym świecie naukowym: kontynentalną (europejska), anglo-amerykańska i sowiecka. Ich specyfika nie pociaga za soba ściśle geograficznego przypisania danego filozofa do określonego typu filozofii, co ma związek $z$ różnym w ich obrębie podejściem do 
podmiotu. W kontekście charakterystyki filozofii autorstwa Tymienieckiej ważne byłyby dwie pierwsze grupy. Bocheński twierdził, że w tak zwanej filozofii kontynentalnej często dostrzega się akcentowanie problematyki samego człowieka, natomiast w nurcie anglo-amerykańskim - nauki o wszechświecie. Uważał jednak, że poszczególne typy uprawiania filozofii nie tyle się różnia, co dopełniają ${ }^{52}$.

Tymczasem reprezentanci różnych prądów myślowych nie rozmawiaja ze sobą. Będa oni, w najlepszym razie, słuchać uprzejmie swoich kolegów $z$ innych obozów, ale prawie nie włączaja się do dyskusji. Praktycznie nigdy nie czytaja książek pochodzących od grup będacych w opozycji do ich grupy. Nie ma dialogu między nimi ${ }^{53}$.

Powyższa uwaga Bocheńskiego poczyniona została pod adresem przedstawicieli nurtów europejskiego-kontynentalnego i anglo-amerykańskiego. Tymieniecka proponuje coś nowego, na miarę czasów współczesnych: podejście filozoficzne, które wchodzi w bogata głębię fenomenologicznego nurtu stworzonego przez Husserla, nawiązujac dialog nie tylko $z$ innymi koncepcjami i stanowiskami filozoficznymi, ale także ze wszystkimi dziedzinami ludzkich zmagań twórczych. Oparciem dla takiej postawy jest przekonanie polskiej filozof o oczywistej obecności fenomenologii życia w nich wszystkich, nie tylko w filozofii, ale również w naukach szczegółowych, literaturze, sztuce, a nawet w religii ${ }^{54}$. Podsumowujacc, należy zgodzić się $z$ opinią Yvanki B. Raynovej, że Tymieniecka stworzyła światowa platformę badań fenomenologicznych, dzięki czemu stało się możliwe mówienie o chińskiej czy japońskiej fenomenologii życia oraz o dialogu filozofii zachodniej $z$ islamska myśla fenomenologiczna ${ }^{55}$. To bez watpienia wielkie osiagnięcie Polski stało się zadaniem, którego kontynuacja realizuje się nieustannie za sprawa Światowego Instytutu Fenomenologii.

\footnotetext{
52 J.M. Bocheński, Foreword, w: A.T. Tymieniecka, Phenomenology and Science in Contemporary European Thought..., s. VII-VIII.

53 Ibidem, s. VIII (tłumaczenie własne).

54 Ibidem, s. IX.

55 Y.B. Raynova, In Memoriam Ana Teresa Tymieniecka..., s. 77.
} 


\section{Polish Phenomenology Abroad at the Turn of the Twentieth and Twenty-First Centuries: The Key Assumptions of Anna Teresa Tymieniecka's Phenomenology of Life}

This article in a brief way outlines the main assumptions of the concept of the phenomenology of life by contemporary Polish philosopher Anna Teresa Tymieniecka (1923-2014). Tymieniecka pointed out these assumptions in one of her statements presented at the Congress of Polish Culture in London in 1985. The purpose of the philosophical section was to outline the situation of Polish philosophy and Polish culture in exile in the context of the crisis in European culture. Tymieniecka, who was an active scholar in the United States, presented her own point of view on this crisis stating that its source was the absence of communication between various fields of knowledge and also between general science and other forms of human cultural activity. She also presented her own vision of overcoming this crisis in the form of the phenomenology of the human creative condition as the new mathesis universalis.

Keywords: mathesis universalis, Polish philosophy, emigration, interdisciplinary dialogue, New Enlightenment. 